\title{
Effects of Spent and Deoiled Bleaching Earth Filler-Based NPK Fertilization on the Soil Nutrient Status and Growth of Soybean (Glycine max (L.) Merrill)
}

\author{
Muhammad Parikesit Wisnubroto, Eka Tarwaca Susila Putra*, and Budiastuti Kurniasih \\ Department of Agronomy, Faculty of Agriculture, Universitas Gadjah Mada, Yogyakarta, Indonesia \\ "Corresponding author: eka.tarwaca.s@ugm.ac.id
}

\begin{abstract}
The bleaching process at the crude palm oil (CPO) refinery stage is one of the processes sufficient to determine the quality of the cooking oil produced. CPO is refined to eliminate the unacceptable substances before consumption. The process produces spent bleaching earth (SBE) and deoiled bleaching earth (DBE) classified as hazardous and toxic material waste. However, according to several studies, SBE and DBE have the potential as filler materials in NPK fertilizers. This study aimed to study the effect of SBE and DBE filler-based NPK fertilization on the soil nutrient status and growth characteristics of soybean, thereby determining if the SBE and DBE materials can be used to replace some of the filler components in the NPK fertilizers. The study was a single factor experiment arranged in a Randomized Complete Block Design (RCBD) consisting of four blocks as replications. The treatments tested were fertilization of $10 \%$ bentonite clay mineral filler-based NPK (control), $5 \%$ bentonite clay mineral $+5 \%$ SBE filler-based NPK and 5\% bentonite clay mineral $+5 \%$ DBE filler-based NPK. The data were analyzed using ANOVA and tested using LSD test at a 95\% confidence level. The results showed that the SBE and DBE materials could partially replace the filler components in bentonite clay filler-based NPK fertilizers, which were shown to have the same effect on soil chemical properties and levels of heavy metals after treatment, levels and uptake of $\mathrm{N}, \mathrm{P}, \mathrm{K}, \mathrm{Ca}$ and $\mathrm{Mg}$ in plants tissues and growth characteristic in the form of total dry weight.
\end{abstract}

Keywords: deoiled bleaching earth; NPK; nutrient status; soybean; spent bleaching earth

Cite this as: Wisnubroto, M. P., Putra, E, T. S., \& Kurniasih, B. (2021). Effects of Spent and Deoiled Bleaching Earth Filler-Based NPK Fertilization on the Soil Nutrient Status and Growth of Soybean (Glycine max (L.) Merrill). Caraka Tani: Journal of Sustainable Agriculture, 36(2), 213-226. doi: http://dx.doi.org/10.20961/ carakatani.v36i2.43847

\section{INTRODUCTION}

Crude palm oil (CPO) is one of the basic edible vegetable oils used in almost every food processing industries. CPO is extracted from the ripened mesocarp of the fruits of oil palm tree (Elaeis guineensis Jacq.) (Mba et al., 2015). CPO is refined to eliminate the unacceptable substances before consumption. Minor components, including oxidation products, free fatty acids, phospholipids, pigments, trace metals and other impurities, are discharged during refining
(Vispute and Dabhade, 2018). The bleaching process at the CPO refinery stage is one of the processes sufficient to determine the quality of the cooking oil produced. CPO bleaching can be done using adsorbents, such as bleaching earth. The spent bleaching earth (SBE) originating from the bleaching process is the greatest waste in the palm cooking oil industry. The more palm oil is produced, the more waste produced by bleaching in the form of SBE will be created. Meanwhile, based on Government Regulation (PP) of the Republic of Indonesia No. 101 of

\footnotetext{
* Received for publication August 19, 2020

Accepted after corrections February 18, 2021
} 
2014, SBE is categorized as toxic and hazardous waste (B3 waste) due to its potential to cause pollution to soil, water and air (Pasaribu and Sukandar, 2017). SBE and its recovery results in the form of deoiled bleaching earth (DBE) have several filler components derived from CPO, especially in the form of oil and also contain several types of heavy metals, including $\mathrm{Ag}, \mathrm{Cd}$, $\mathrm{Cu}, \mathrm{Ni}$ and $\mathrm{Zn}$ (Loh et al., 2015).

These filler components make SBE and DBE materials flammable and able to pollute the environment due to their heavy metal content. It generates the necessity of innovations in the reuse of SBE and DBE waste because, in addition to being able to solve the problem of B3 waste, these wastes can also be used as economically valuable materials, one of which is as a substitute for filler materials in NPK fertilizers (Sinaga et al., 2021). The type of filler commonly used in NPK fertilizer is bentonite clay (brown clay/BC) that has the same characteristic as bleaching earth (BE) (Anugrah et al., 2020). The utilization of SBE and DBE as a substitute for filler materials in NPK fertilizers can also inhibit the environmental damage from the exploitation of $\mathrm{BC}$ mining so that the environment becomes more sustainable (Wisnubroto et al., 2020). In addition, replacing some of the filler components with SBE and DBE is thought to be able to produce NPK fertilizer that is more slowly available because each of these materials still contains oil residues of $20-30 \%$ (Krisyanti and Sukandar, 2011) and 3-5\% (Chanrai and Burde, 2004), respectively, so as to be able to provide nutrients more efficiently for plants.

However, the effects of using SBE and DBE as a partial substitution of NPK fertilizer filler on the environment and plants still require further evaluation, considering that both materials contain several elements that belong to heavy metals (Purba et al., 2020). Ashfaque et al. (2016) state that heavy metals have adverse effects on physiological and biochemical function of plants, most obvious effects are the inhibition of growth rate, chlorosis, necrosis, leaf rolling, altered stomatal action, decreased water potential, efflux of cations, alterations in membrane functions, inhibition of photosynthesis, respiration, altered metabolism and activities of several key enzymes.

According to Ginting et al. (2013), the addition of nutrients (one of which is through fertilization) can cause a shift in the nutrient balance in the soil, which can then affect the growth and development of cultivated plants on it. Suhariyono and Menry (2005) state that the characteristics of nutrient elements in the soil, both essential and nonessential, greatly influence the characteristics of these elements in plant tissue. The interactions between some of the elements themselves can be an obstacle to the absorption of essential nutrient elements by plants (Mousavi et al., 2012).

In general, the response of plants to nutrients can change depending on the availability status of other nutrients. Based on the relationships, either positive or negative interactions between each nutrient element and the influence of the environment on these interactions in the soil, it is necessary to study the effect of SBE and DBE filler-based NPK fertilization on the soil nutrient status and soybean (Glycine max (L.) Merrill). Pratap et al. (2012) state that the soybean occupies a premier position among agricultural crops, being the most important source of good quality concentrated proteins as well as vegetable oil. The soybean plant is known to be slightly sensitive to the environmental conditions, especially toxic elements such as heavy metals (Taufiq and Sundari, 2012) so that it can be used as a model plant to determine whether SBE and DBE materials can be used to replace some of the filler components in NPK fertilizer based on soil nutrient status and growth characteristics.

\section{MATERIALS AND METHOD}

This study was conducted in October 2018January 2019 at the Field of the Center for Agro-Technology Innovation (PIAT), Universitas Gadjah Mada, Kalitirto, Berbah, Sleman, Yogyakarta, Indonesia, located at an altitude of 124 meters above sea level. The coordinate of the study site lies at latitude of $7^{\circ} 47^{\prime} 23.7^{\prime \prime}-7^{\circ} 47^{\prime} 24.3^{\prime \prime}$ $\mathrm{S}$ and longitude of $110^{\circ} 27^{\prime} 44.2^{\prime \prime}-110^{\circ} 27^{\prime} 44.3^{\prime \prime} \mathrm{E}$. Based on Oldeman's classification, Berbah is included in the C3 climate type, which has 5-6 consecutive wet months and 5-6 dry months (Harmoni, 2014). The type of soil in the location is Regosol that has a coarse texture (high sand fraction) so that it has good porosity, but has a low fertility level because the nutrients are easily washed. The materials used in this study included soybean plants cv. Grobogan that are widely cultivated in the surrounding area and NPK 15:15:15 compound fertilizer with filler materials of $10 \%$ bentonite clay mineral, $5 \%$ mineral clay + $5 \% \mathrm{SBE}$ and $5 \%$ bentonite clay mineral $+5 \%$ 
DBE. These NPK fertilizers contain at least $15 \%$ nitrogen $(\mathrm{N}), 15 \%$ phosphorous pentoxide $\left(\mathrm{P}_{2} \mathrm{O}_{5}\right)$ and $15 \%$ potash $\left(\mathrm{K}_{2} \mathrm{O}\right)$. The color is brown, slightly soluble in water (slow release) and hygroscopic.

The study was a single factor field experiment in a randomized complete block design (RCBD) with four blocks as replications. The treatments tested consisted of $10 \%$ bentonite clay fillerbased NPK fertilization (control), 5\% bentonite clay $+5 \%$ SBE filler-based NPK fertilization and $5 \%$ bentonite clay $+5 \%$ DBE filler-based NPK fertilization. The SBE and DBE used were obtained from PT. Sentana Adidaya Pratama (SADP), which is a subsidiary of the Wilmar Group Indonesia. Minimum soil tillage was carried out and the planting space was $40 \mathrm{~cm}$ x $20 \mathrm{~cm}$ with two seeds per planting hole. The experimental plot was $10 \mathrm{~m} \times 8 \mathrm{~m}$ with the height of the raised bed of $30 \mathrm{~cm}$. The distance between beds was $0.5 \mathrm{~m}$ and the distance between blocks was $1 \mathrm{~m}$. NPK fertilizers in all treatments were given twice, $150 \mathrm{~kg} \mathrm{ha}^{-1}$ and $225 \mathrm{~kg} \mathrm{ha}^{-1}$ at 14 and 35 days after planting (DAP), respectively. Fertilizer was applied using a deep placement system with a distance of $\pm 5 \mathrm{~cm}$ from the roots of the plants so as not to disturb the roots.

The variables observed were the physical and chemical properties of fertilizers based on the method from Hermawan (2017), chemical properties of filler materials by Eviati and Sulaeman (2009), soil chemical properties before and after fertilization treatment (including the levels of heavy metals such as $\mathrm{Ag}, \mathrm{Cd}, \mathrm{Cu}, \mathrm{Ni}$ and $\mathrm{Zn}$ ) observed at 70 DAP by Eviati and Sulaeman (2009), plant growth characteristics in the form of total dry weight observed at 70 DAP (plant dry weight illustrates the accumulation of organic compounds synthesized from inorganic compounds by plants obtained by drying the plant parts in an oven at $80^{\circ} \mathrm{C}$ for \pm 48 hours until reaching constant weight, which is known by weighing the plants several times with an interval of 24 hours), the levels and uptake of essential macronutrients $(\mathrm{N}, \mathrm{P}, \mathrm{K}, \mathrm{Ca}$ and $\mathrm{Mg}$ ) in plant tissues observed at 70 DAP by Eviati and Sulaeman (2009) and the levels of heavy metal $(\mathrm{Ag}, \mathrm{Cd}, \mathrm{Cu}, \mathrm{Ni}$ and $\mathrm{Zn})$ in plant tissues observed at 70 DAP by Eviati and Sulaeman (2009). The data obtained were tested with analysis of variance (ANOVA). The variables showing significant differences between treatments were then tested with the Least Significant Difference (LSD) test at 5\%. The data analysis process was carried out using the SAS software version 9.4. The relationship between heavy metal elements and essential macronutrients ( $\mathrm{N}, \mathrm{P}, \mathrm{K}, \mathrm{Ca}$ and $\mathrm{Mg}$ ) was analyzed with correlation analysis using RStudio software.

\section{RESULTS AND DISCUSSION}

According to Wambu et al. (2009), the bleaching waste materials, namely SBE and its derivative products DBE, are potential filler resources in NPK fertilizers, substituting bentonite clay minerals (brown clay). They have high oil content and can be regenerated and reused.

\section{Physical properties of the fertilizers with various filler materials}

The substitution of $5 \%$ of the filler materials with SBE and DBE is thought to produce slowrelease NPK fertilizer. These ingredients contain oil residue to provide nutrients more efficiently for plants. The physical properties of the NPK fertilizers observed in this study are presented in Figure 1.

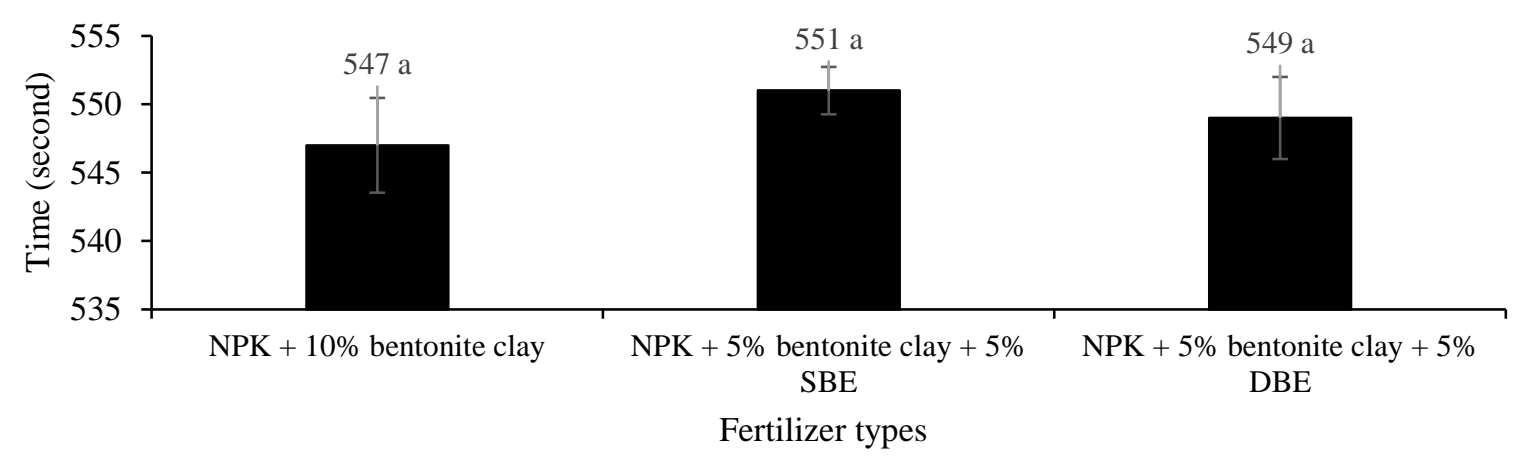

Note: The data displayed are mean \pm standard deviation; means followed by the same letters are not significantly different according to the LSD test at $5 \%$

Figure 1. The solubility of NPK fertilizer with different types of filler materials 
Figure 1 shows that partial substitution of the filler materials in NPK fertilizer doesn't significantly affect the solubility of fertilizers in water. Although it is not statistically significant, a slower fertilizer release using SBE and DBE is most likely due to the oil content in the SBE and DBE materials, making the fertilizers become more hydrophobic and inhibits the hydrolysis of fertilizers by water.
Chemical properties of various filler materials Bentonite clay mineral (BC) is characteristically the same as BE used in the bleaching process of CPO. However, the heavy metal content in SBE and DBE materials requires further study of this waste utilization innovation. The content of heavy metals in BC, SBE and DBE materials before being processed into part of NPK fertilizer can be seen in Table 1.

Table 1. Heavy metal content in BC, SBE and DBE

\begin{tabular}{lcccccc}
\hline \multirow{2}{*}{ Filler material } & \multicolumn{5}{c}{ Heavy metal content $(\mathrm{ppm})$} \\
\cline { 2 - 6 } & $\mathrm{Ag}$ & $\mathrm{Cd}$ & $\mathrm{Cu}$ & $\mathrm{Ni}$ & $\mathrm{Zn}$ \\
\hline $\mathrm{BC}$ & $4.19 \mathrm{~b}$ & $6.38 \mathrm{a}$ & $38.90 \mathrm{~b}$ & $29.46 \mathrm{~b}$ & $132.03 \mathrm{~b}$ \\
$\mathrm{SBE}$ & $3.45 \mathrm{~b}$ & $4.23 \mathrm{~b}$ & $18.90 \mathrm{c}$ & $15.27 \mathrm{~b}$ & $106.96 \mathrm{c}$ \\
$\mathrm{DBE}$ & $12.35 \mathrm{~b}$ & $5.47 \mathrm{a}$ & $70.85 \mathrm{a}$ & $50.82 \mathrm{a}$ & $208.35 \mathrm{a}$ \\
\hline \multicolumn{2}{c}{$\mathrm{CV}(\%)$} & 11.10 & 9.09 & 3.36 & 20.34 & 0.96 \\
\hline
\end{tabular}

Note: Means followed by the same letters are not significantly different according to the LSD test at 5\%

Table 1 shows the analysis of heavy metal content such as $\mathrm{Ag}, \mathrm{Cd}, \mathrm{Cu}, \mathrm{Ni}$ and $\mathrm{Zn}$ in $\mathrm{BC}, \mathrm{SBE}$ and DBE. The analysis indicated that DBE material contained a significantly higher level of $\mathrm{Cu}, \mathrm{Ni}$ and $\mathrm{Zn}$ than SBE and BC. Meanwhile, the level of $\mathrm{Cd}$ was significantly higher in $\mathrm{BC}$ and DBE than in SBE. There was no significant difference in the Ag level between the three types of filler materials. This result is most likely because the extracted oil (in processing SBE into DBE) makes some of these heavy metals more concentrated.

\section{Chemical properties of the NPK fertilizers with various filler materials}

$\mathrm{BC}, \mathrm{SBE}$ and DBE were processed into filler materials for NPK fertilizer whose heavy metal content is presented in Table 2 .

Table 2. The levels of heavy metals contained in NPK fertilizer with various filler materials

\begin{tabular}{lccccc}
\hline \multirow{2}{*}{ Treatments } & \multicolumn{5}{c}{ Levels of heavy metal (ppm) } \\
\cline { 2 - 6 } & $\mathrm{Ag}$ & $\mathrm{Cd}$ & $\mathrm{Cu}$ & $\mathrm{Ni}$ & $\mathrm{Zn}$ \\
\hline $\mathrm{NPK}+10 \%$ bentonite clay & $7.03 \mathrm{~b}$ & undetected & $23.76 \mathrm{~b}$ & $0.25 \mathrm{~b}$ & $47.28 \mathrm{c}$ \\
$\mathrm{NPK}+5 \%$ bentonite clay $+5 \% \mathrm{SBE}$ & $4.51 \mathrm{c}$ & undetected & $43.95 \mathrm{a}$ & $5.03 \mathrm{a}$ & $54.85 \mathrm{a}$ \\
$\mathrm{NPK}+5 \%$ bentonite clay + 5\% DBE & $9.15 \mathrm{a}$ & undetected & $44.10 \mathrm{a}$ & $3.45 \mathrm{ab}$ & $50.69 \mathrm{~b}$ \\
\hline \multicolumn{1}{c}{$\mathrm{CV}(\%)$} & 14.37 & - & 3.13 & 99.20 & 2.35 \\
\hline Critical limit of heavy metal content in & - & 20 & - & 180 & 1,850 \\
inorganic fertilizer $(\mathrm{ppm}) *$ & & & & \\
\hline Note: Means followed by the same letters are not significantly different according to the LSD test at 5\%. \\
The level of Cd was not detected, meaning that it was below the detection limit of the measurement \\
tool (detection limit = 0.01 ppm). *Critical limit of heavy metal content inorganic fertilizers by Benson \\
(2014)
\end{tabular}

The level of heavy metal content decreased significantly after the $\mathrm{BC}, \mathrm{SBE}$ and $\mathrm{DBE}$ materials were processed to become part of the NPK filler materials. The $\mathrm{Cd}$ levels were not detected or below the detection limit of the measurement tool (Table 2). This result could happen because the material was only used in small amounts in NPK fertilizer. SBE and DBE were only used to partially substitute $(5 \%)$ the filler materials in NPK fertilizers.

The results also showed that the SBE and DBE filler-based NPK fertilizers had higher levels of $\mathrm{Cu}$ and $\mathrm{Ni}$. Meanwhile, the level of $\mathrm{Zn}$ and $\mathrm{Ag}$ was significantly higher in NPK fertilizers with SBE and DBE, respectively. Overall, the DBE filler-based NPK showed higher heavy metal content than the BC filler-based NPK. 
However, the levels of heavy metals contained in all NPK fertilizers used in this study were still below the critical limit for heavy metal elements in inorganic fertilizers (Table 2).

The higher content of heavy metals in DBE and SBE filler-based NPK because SBE is a residual material in the bleaching process, which in addition to removing dyes, can also reduce other unwanted components such as heavy metals. According to Emamverdian et al. (2015), heavy metals can be divided into two types. The first type is the essential heavy metals needed by organisms but causing toxic effects in excessive amounts, such as $\mathrm{Zn}, \mathrm{Cu}, \mathrm{Fe}, \mathrm{Mn}$ and $\mathrm{Ni}$. The second type is the non-essential heavy metals, whose benefits are still unknown and are even toxic, such as $\mathrm{Hg}, \mathrm{Cd}, \mathrm{Pb}, \mathrm{Cr}$ and $\mathrm{Ag}$. It shows that the presence of heavy metals in SBE and DBE materials used to substitute 5\% of the filler materials in NPK fertilizers could be beneficial for plants as long as their levels are still within the optimal limit.

\section{Soil chemical properties}

Soil as a medium to grow plants is one factor that can affect plant growth, either on physical, chemical (Erizilina et al., 2018) or biological characteristics (Delgado and Gómez, 2016). The soil properties greatly influence the characteristics of the elements in the plants that grow on it. The soil type in this research is Regosol. The results of research by Sonbai et al. (2013) showed that Regosol soil was dominated by a sand fraction $(82.61 \%)$ followed by silt fraction $(12.97 \%)$ and clay fraction $(5.42 \%)$ so it was included in the sand texture class. Soil with this physical property is difficult to hold water, making not all plants suitable for this soil. Apart from its physical properties, Regosol soil also has poor chemical properties, indicated by low CEC (6.04 me $100 \mathrm{~g}-$ $\left.{ }^{1}\right)$ and organic C (0.94\%). Mustikawati et al. (2019) add that Regosol soil is poor in organic matter, resulting in low ability to store water and nutrients. The results of the analysis of soil chemical properties are presented in Table 3.

Table 3. Analysis of soil chemical properties before and after various fillers-based NPK fertilization treatments

\begin{tabular}{|c|c|c|c|c|c|c|}
\hline \multirow{2}{*}{ Variables } & \multirow{2}{*}{ Unit } & \multirow{2}{*}{$\begin{array}{c}\text { Before } \\
\text { treatment }\end{array}$} & \multicolumn{4}{|c|}{ After treatments (70 DAP) } \\
\hline & & & $\mathrm{BC}$ & SBE & $\mathrm{DBE}$ & $\mathrm{CV}(\%)$ \\
\hline $\mathrm{pH}\left(\mathrm{H}_{2} \mathrm{O}\right)$ & & $6.96 \mathrm{~N}$ & $7.16 \mathrm{a}(\mathrm{N})$ & $6.62 \mathrm{a}(\mathrm{N})$ & $7.04 \mathrm{a}(\mathrm{N})$ & 9.37 \\
\hline SOC & $\%$ & $1.30 \mathrm{~L}$ & $1.1 \mathrm{a}(\mathrm{L})$ & $1.26 \mathrm{a}(\mathrm{L})$ & $1.22 \mathrm{a}(\mathrm{L})$ & 26.42 \\
\hline Total N & $\%$ & $0.07 \mathrm{EL}$ & $0.07 \mathrm{a}(\mathrm{EL})$ & $0.07 a(E L)$ & $0.07 \mathrm{a}(\mathrm{EL})$ & 13.04 \\
\hline Potential $\mathrm{P}_{2} \mathrm{O}_{5}$ & $\operatorname{mg} 100 \mathrm{~g}^{-1}$ & $139 \mathrm{EH}$ & $139.67 \mathrm{a}(\mathrm{EH})$ & $144.33 \mathrm{a}(\mathrm{EH})$ & $156.33 \mathrm{a}(\mathrm{EH})$ & 8.73 \\
\hline Potential $\mathrm{K}_{2} \mathrm{O}$ & $\operatorname{mg} 100 \mathrm{~g}^{-1}$ & $31 \mathrm{M}$ & $45.33 \mathrm{a}(\mathrm{H})$ & $48.33 \mathrm{a}(\mathrm{H})$ & $48.33 \mathrm{a}(\mathrm{H})$ & 10.21 \\
\hline Available P & ppm & $11 \mathrm{M}$ & $36 \mathrm{a}(\mathrm{EH})$ & 28.33a (EH) & $13 \mathrm{a}(\mathrm{M})$ & 47.89 \\
\hline Available K & ppm & $2 \mathrm{EL}$ & $182 \mathrm{a}(\mathrm{EH})$ & $135 \mathrm{a}(\mathrm{EH})$ & $118 \mathrm{a}(\mathrm{EH})$ & 31.76 \\
\hline Ca-dd & $\operatorname{cmol}(+) \mathrm{kg}^{-1}$ & $3.86 \mathrm{~L}$ & 4.27a (L) & 3.68a (L) & $2.91 \mathrm{a}(\mathrm{L})$ & 19.23 \\
\hline Mg-dd & $\operatorname{cmol}(+) \mathrm{kg}^{-1}$ & $1.25 \mathrm{M}$ & $1.85 \mathrm{a}(\mathrm{M})$ & $1.63 \mathrm{a}(\mathrm{M})$ & $1.43 \mathrm{a}(\mathrm{M})$ & 24.97 \\
\hline CEC & $\operatorname{cmol}(+) \mathrm{kg}^{-1}$ & $6.16 \mathrm{~L}$ & $8.54 \mathrm{a}(\mathrm{L})$ & 8.01a (L) & 7.71a (L) & 12.92 \\
\hline
\end{tabular}

Note: $\mathrm{BC}=\mathrm{NPK}+10 \%$ bentonite clay (control); $\mathrm{SBE}=\mathrm{NPK}+5 \%$ bentonite clay $+5 \% \mathrm{SBE}$; DBE $=\mathrm{NPK}+$ $5 \%$ bentonite clay $+5 \%$ DBE; DAP $=$ days after planting; $\mathrm{SOC}=$ soil organic carbon; $\mathrm{CEC}=$ cation exchange capacity. *Means followed by the same letters are not significantly different according to the LSD test at 5\%.**Based on the criteria of general soil analysis (Eviati and Sulaeman, 2009): EL = Extremely low; L = Low; $\mathrm{M}=$ Moderate; $\mathrm{N}=$ Neutral; $\mathrm{H}=\mathrm{High}$; and $\mathrm{EH}=$ Extremely high

The results showed that the soil chemical properties in three treatments at 70 DAP was not significantly affected by the fertilization treatments, which shows that the use of SBE and DBE doesn't affect the two observed variables (Table 3). Nitrogen $(\mathrm{N})$ is a nutrient needed by plants in large quantities for the entire growth process. In plants, $\mathrm{N}$ functions as the main component of proteins, hormones, chlorophyll, vitamins and enzymes essential for plant life.
This study revealed that the total $\mathrm{N}$ content in the soil before treatment was classified as extremely low. Similarly, the total $\mathrm{N}$ in the soil after the treatment was low for the three treatments (Table 3). This result is most likely because $\mathrm{N}$ is very mobile. It could have transformed into other form and may lose from the soil system due to denitrification, volatilization, transport of crops, leaching and soil surface erosion (Nariratih et al., 2013). Moreover, it can 
be due to the type of soil in the location is Regosol that has a coarse texture (high sand fraction) with low SOC content and low CEC.

Phosphorus $(\mathrm{P})$ is an essential macro element that is immobile in the soil. This element functions as a constituent of DNA, cell membranes and is a component of the ATP compound that acts as a source of energy for plant growth. Excess $\mathrm{P}$ inhibits growth due to the occurrence of N-P bonds, making it difficult to absorb $\mathrm{N}$ by plants (Tjahjadi, 1989). The test results in Table 3 show that the soil potential $\mathrm{P}_{2} \mathrm{O}_{5}$ value before fertilization was extremely high. The fertilization treatment increased potential $\mathrm{P}_{2} \mathrm{O}_{5}$ in the soil, although it was still in the extremely high category. The level of phosphorus concentration in the soil is influenced by the amount and type of soil minerals, soil $\mathrm{pH}$, the influence of cations and anions, the level of $\mathrm{P}$ saturation, organic matter, time and temperature and inundation (Nursyamsi and Setyorini, 2009).

Potassium $(\mathrm{K})$ is an essential macronutrient for plants that are highly mobile as $\mathrm{K}^{+}$so that the initial symptoms of its deficiency will appear on old leaves. The $\mathrm{K}$ element functions in the activity of turgor cells, which directly spurs the opening and closing of the stomata, keeps the stem upright and stimulates the accumulation and translocation of assimilates from source to sink (Apriliani et al., 2016). The excess of $\mathrm{K}$ inhibits growth due to the occurrence of $\mathrm{N}-\mathrm{K}$ bonds, which makes it difficult for plants to absorb N (Tjahjadi, 1989). The test results showed that the potential $\mathrm{K}$ value in the planting medium before treatment was moderate. Meanwhile, after treatment, the potential $\mathrm{K}$ value increased, classified as high in the three treatments (Table 3 ). High $\mathrm{K}$ recorded after treatments could be due to the retention ability of the SBE, DBE and $\mathrm{BC}$ for $\mathrm{K}$.

The low levels of $\mathrm{Ca}^{2+}$ and $\mathrm{Mg}^{2+}$ base cations are caused by low soil organic matter so that the decomposition process by living bodies is low and only little nutrients are released (Sevindrajuta, 1996). The low concentration of cations can also be due to poor concentrations of the alkaline cation in the rocks making up the soil in the area, high rainfall in the tropics leading to intensive leaching and the absorption of base cations by plants.

Calcium $(\mathrm{Ca})$ acts as a constituent of cell walls, maintains cell integrity and cell membrane permeability, activates enzymes and neutralizes heavy metal elements in plants (Taufiq, 2014). The test results depicted that the availability of Ca-dd in the soil before treatment was classified as low. After the treatment, the BC filler-based NPK fertilization increased the Ca-dd value, while the SBE and DBE filler-based NPK fertilization decreased the value, although the values in the three treatments were low (Table 3).

Magnesium (Mg) is a component of the chlorophyll molecules, which plays a role in activating enzymes in the phosphorylation process and helps the distribution of phosphorus throughout the plant body. The test results confirmed that the availability of $\mathrm{Mg}$-dd in the soil was in the moderate criteria. The fertilization treatments increased the Mg-dd level in the three treatments, although it was still classified as moderate (Table 3 ).

Soil naturally contains various types of heavy metals (Alloway, 1995). According to Handayanto et al. (2017), these heavy metals come from the weathering of the soil parent materials at low levels and are generally nontoxic. Besides, heavy metals in the soil can be sourced from human (anthropogenic) activities, which contribute more than natural sources. The soil pollutant metals from anthropogenic sources include fertilizers, both inorganic and organic fertilizers, pesticides and mining (Erfandy and Juarsah, 2014). All NPK fertilizers used in this study were known to contain several types of heavy metals such as $\mathrm{Ag}, \mathrm{Cd}, \mathrm{Cu}$, $\mathrm{Ni}$ and $\mathrm{Zn}$ which, when applied, could indirectly contaminate the soil, although some of them belong to essential heavy metal elements such as $\mathrm{Cu}, \mathrm{Ni}$ and $\mathrm{Zn}$ (Table 2).

The levels of heavy metals in the soil at the research location, before and after the fertilization treatments, are presented in Table 4. The levels of various types of heavy metals $(\mathrm{Ag}, \mathrm{Cd}, \mathrm{Cu}, \mathrm{Ni}$ and $\mathrm{Zn}$ ) in the soil at the study site before treatment were below the critical limit of metals in the soil according to Alloway (1995), except Ag (silver), which exceeds the critical limit (Table 4). The fertilization treatments increased the levels of $\mathrm{Cu}$ and $\mathrm{Zn}$ but still below the critical limit. The levels of $\mathrm{Ag}$ in the soil after the fertilization treatments also increased, except in the $\mathrm{BC}$ treatment, exceeding the critical limit in the soil. These results indicate that the addition of fertilizer affects the increase in the Ag level of the soil in 
the three treatments so that it exceeds the critical limit. Excessive levels of $\mathrm{Ag}$ can be harmful to plants because they can hinder germination by inhibiting cell elongation in roots, damaging cell walls and vacuoles, as well as reducing the absorption of magnesium, phosphorus and sulfur nutrients, thereby disrupting root formation (Shofi, 2017).

Table 4. The levels of heavy metals in the soil before and after the treatments of various fillers-based NPK fertilization

\begin{tabular}{|c|c|c|c|c|c|c|}
\hline \multirow{2}{*}{$\begin{array}{l}\text { Heavy } \\
\text { metal }\end{array}$} & \multirow{2}{*}{$\begin{array}{l}\text { Before treatment } \\
\quad(\mathrm{ppm})\end{array}$} & \multicolumn{4}{|c|}{ After treatment at 70 DAP (ppm) } & \multirow{2}{*}{$\begin{array}{l}\text { Critical limit of heavy metal } \\
\text { content in the soil (ppm)* }\end{array}$} \\
\hline & & $\mathrm{BC}$ & SBE & DBE & CV (\%) & \\
\hline $\mathrm{Ag}$ & 9.17 & $6.87 \mathrm{a}$ & $9.30 \mathrm{a}$ & $9.42 \mathrm{a}$ & 45.76 & 2 \\
\hline $\mathrm{Cd}$ & 0.10 & undetected & undetected & undetected & - & $3-8$ \\
\hline $\mathrm{Cu}$ & 2.80 & $38.47 \mathrm{a}$ & $55.52 \mathrm{a}$ & $37.79 \mathrm{a}$ & 15.74 & $60-125$ \\
\hline $\mathrm{Ni}$ & 47.73 & undetected & undetected & undetected & - & 100 \\
\hline $\mathrm{Zn}$ & 0.10 & $74.25 \mathrm{a}$ & $79.16 \mathrm{a}$ & $88.90 \mathrm{a}$ & 12.08 & $70-400$ \\
\hline
\end{tabular}

Note: Means followed by the same letters are not significantly different according to the LSD test at $5 \%$. The level of $\mathrm{Cd}$ and $\mathrm{Ni}$ after treatment was not detected, meaning that it was below the detection limit of the measurement tool (detection limit of $\mathrm{Cd}=0.01 \mathrm{ppm}$ and $\mathrm{Ni}=0.25 \mathrm{ppm}$ ). *Critical limit of heavy metal content inorganic fertilizers by Alloway (1995); $\mathrm{BC}=\mathrm{NPK}+10 \%$ bentonite clay; $\mathrm{SBE}=\mathrm{NPK}+5 \%$ bentonite clay $+5 \% \mathrm{SBE} ; \mathrm{DBE}=\mathrm{NPK}+5 \%$ bentonite clay $+5 \% \mathrm{DBE}$

Ag ions, both monovalent and nanoparticles, have antimicrobial properties that are used for various purposes such as bactericides (Barrena et al., 2009) so that their presence in the soil can trigger unfavorable effects on the beneficial bacteria. Ag poisoning varies between plant species from highly toxic to easily inactivated by plants. In soybean plants, the treatment of $\mathrm{Ag}$ nanoparticles up to a concentration of $30 \mathrm{ppm}$ on the soil did not show a significant effect on the fresh weight of roots, although it tended to decrease with increasing doses given ( $\mathrm{Li}$ et al.,
2017). This result signifies that the presence of $\mathrm{Ag}$ metal in the soil at the research location, before and after treatment, was still classified as safe for the growth and development of soybean plants.

\section{Growth characteristics}

One of the variables used to measure plant growth characteristics is plant dry weight. Soeparjono (2016) suggests that dry weight reflects the accumulation of organic compounds synthesized from inorganic compounds (water, $\mathrm{CO}_{2}$ and nutrients) through photosynthesis.

Table 5. Total dry weight of soybean plants as affected by various fertilization at 70 DAP

\begin{tabular}{cc}
\hline \multicolumn{1}{c}{ Treatment } & Total dry weight $\left(\mathrm{g} \mathrm{plant}^{-1}\right)$ \\
\hline NPK $+10 \%$ bentonite clay & $56.50 \mathrm{a}$ \\
NPK $+5 \%$ bentonite clay $+5 \%$ SBE & $64.75 \mathrm{a}$ \\
NPK $+5 \%$ bentonite clay $+5 \%$ DBE & $65.80 \mathrm{a}$ \\
\hline CV $(\%)$ & 12.94
\end{tabular}

Note: Means followed by the same letters are not significantly different according to the LSD test at 5\%

The results showed that the total dry weight of soybean plants in the three treatments at 70 DAP was not significantly affected by the fertilization treatments, signifying that the use of SBE and DBE doesn't affect the two observed variables (Table 6). However, the use of 5\% SBE and DBE in NPK fertilizer increased the total dry weight of soybean plants by $14.60 \%$ and $16.46 \%$, respectively. This result is most likely due to the level of essential heavy metals in the form of $\mathrm{Zn}$, which was higher in the soil after the treatment of 5\% SBE and DBE filler-based
NPK fertilizer compared to the control treatment at 70 DAP (Table 5).

\section{The levels of heavy metals in the plant tissues}

In plants, heavy metals can enter the tissue through roots and stomata (Alloway, 1995). Heavy metals such as $\mathrm{Cu}, \mathrm{Ni}$ and $\mathrm{Zn}$ are essential elements needed by plants in small amounts but in high levels can inhibit plant growth. Meanwhile, $\mathrm{Ag}, \mathrm{Cd}, \mathrm{Cr}$ and $\mathrm{Pb}$ metals are non-essential elements that inhibit plant growth (Rai et al., 2019). 
Table 6. The levels of heavy metals in the soybean plant tissues as affected by various fertilization treatments at 70 DAP

\begin{tabular}{ccccc}
\hline Heavy metal & Treatment & $\begin{array}{c}\text { The level of heavy metal } \\
\text { in plant tissues (ppm)* }\end{array}$ & CV (\%) & $\begin{array}{c}\text { Critical limit of heavy metal } \\
\text { content in soybean (ppm) }\end{array}$ \\
\hline $\mathrm{Ag}$ & $\mathrm{BC}$ & $2.01 \mathrm{a}$ & 12.62 & $1-30$ \\
& $\mathrm{SBE}$ & $2.45 \mathrm{a}$ & & Li et al. (2017) \\
& $\mathrm{DBE}$ & $1.93 \mathrm{a}$ & & $100-500$ \\
$\mathrm{Cu}$ & $\mathrm{BC}$ & $47.53 \mathrm{a}$ & 12.13 & Nair and Chung (2014) \\
& $\mathrm{SBE}$ & $31.42 \mathrm{a}$ & & $50-100$ \\
& $\mathrm{DBE}$ & $43.09 \mathrm{a}$ & & Fitriani et al. (2019) \\
\hline $\mathrm{Ni}$ & $\mathrm{BC}$ & $2.91 \mathrm{a}$ & 30.63 & $150-200$ \\
& $\mathrm{SBE}$ & $9.89 \mathrm{a}$ & & Fageria et al. (1997) \\
\hline $\mathrm{Zn}$ & $\mathrm{DBE}$ & $8.70 \mathrm{a}$ & & \\
& $\mathrm{BC}$ & $78.21 \mathrm{~b}$ & 2.93 & \\
& $\mathrm{SBE}$ & $81.56 \mathrm{~b}$ & & \\
& $\mathrm{DBE}$ & $94.54 \mathrm{a}$ &
\end{tabular}

Note: Means followed by the same letters in the same column are not significantly different according to the LSD test at 5\%. The level of $\mathrm{Cd}$ was not detected, meaning that it was below the detection limit of the measurement tool (detection limit of $\mathrm{Cd}=0.01 \mathrm{ppm}$ ). $\mathrm{BC}=\mathrm{NPK}+10 \%$ bentonite clay; $\mathrm{SBE}=\mathrm{NPK}+$ $5 \%$ bentonite clay $+5 \% \mathrm{SBE} ; \mathrm{DBE}=\mathrm{NPK}+5 \%$ bentonite clay $+5 \% \mathrm{DBE}$

The results showed that the treatments given did not have a significant effect on the level of heavy metals in plant tissues at 70 DAP, except $\mathrm{Zn}$. All types of metals contained in plant tissue were still below the critical limit for soybean plants, even the presence of Cd was not detected, meaning that the level was below the tool detection limit of $0.01 \mathrm{ppm}$. This result is directly proportional to the levels of $\mathrm{Cd}$ in fertilizer and soil in this study (Table 6).

The level of $\mathrm{Zn}$ in DBE filler-based NPK treatment was significantly higher compared to that in the control treatment. According to Smith (1982), $\mathrm{Zn}$ is one of the micronutrients needed by plants in small amounts, which plays an important role in the nodulation process and nitrogen fixation and is involved in the synthesis of leghemoglobin. Sharma et al. (1994) add that $\mathrm{Zn}$ acts as a cofactor for the formation of carbonic anhydrase (CA) enzymes and an enzyme that acts as an antioxidant, namely superoxide dismutase (SOD). In the carbonic anhydrase enzyme, $\mathrm{Zn}$ becomes the single element that forms the enzyme. The CA enzyme plays a role in catalyzing the hydration reaction of $\mathrm{CO}_{2}$ with water to become $\mathrm{HCO}_{3}{ }^{-}$and $\mathrm{H}^{+}$and vice versa. This process causes the availability of $\mathrm{CO}_{2}$ in the leaf cells to remain sufficient for photosynthesis. The $\mathrm{Zn}$ nutrients, together with $\mathrm{Cu}$, bind to the SOD enzyme to form
CuZnSOD that is widely available in plant cells to minimize oxidative stress in plants. The higher levels of $\mathrm{Zn}$ in plant tissue treated with the DBE filler-based NPK fertilization is most likely because the material has nanosized pores that had been left behind by oil due to the deoiling process. The pores are then filled with minerals so that they can help provide these elements for plants.

\section{Levels and uptake of various essential macro- nutrients in plant tissues}

Siedlecka (1995) states that heavy metals are aggressive environmental pollutants because heavy metals are easily taken up by plants and are a strong stress factor in plant metabolism. The effect of heavy metals includes disturbances in the absorption of nutrients by plants due to competition with other nutrients. The typical symptoms of heavy metal poisoning are often the same or even the same as the symptoms of some essential nutrient deficiencies. The mechanism of interaction in heavy metals is very complex and little is known. Heavy metals can inhibit the absorption of other nutrients through competition, influence on root membranes (root membrane lipid peroxidation or protein breakdown), inhibition of ATPase and other carriers, decreased root respiration (reduced active transport) and impaired root growth decreasing area at the root tip that does not contain suberin, thereby 
affecting the permeability of root cells that act as a barrier. The levels of nutrients $(\mathrm{N}, \mathrm{P}, \mathrm{K}, \mathrm{Ca}$ and $\mathrm{Mg}$ ) in soybean plant tissues composite are presented in Table 7.

Table 7. The levels of $\mathrm{N}, \mathrm{P}, \mathrm{K}, \mathrm{Ca}$ and $\mathrm{Mg}$ in soybean plant tissues as affected by various fertilization treatments at $70 \mathrm{DAP}$

\begin{tabular}{cccccc}
\hline Treatment & $\mathrm{N}(\%)$ & $\mathrm{P}(\%)$ & $\mathrm{K}(\%)$ & $\mathrm{Ca}(\%)$ & $\mathrm{Mg}(\%)$ \\
\hline $\mathrm{NPK}+10 \%$ bentonite clay & $3.56 \mathrm{a}$ & $0.11 \mathrm{a}$ & $0.73 \mathrm{a}$ & $2.32 \mathrm{a}$ & $0.32 \mathrm{a}$ \\
$\mathrm{NPK}+5 \%$ bentonite clay + 5\% SBE & $4.16 \mathrm{a}$ & $0.10 \mathrm{a}$ & $0.60 \mathrm{a}$ & $1.94 \mathrm{a}$ & $0.30 \mathrm{a}$ \\
$\mathrm{NPK}+5 \%$ bentonite clay + 5\% DBE & $4.15 \mathrm{a}$ & $0.11 \mathrm{a}$ & $0.68 \mathrm{a}$ & $2.25 \mathrm{a}$ & $0.36 \mathrm{a}$ \\
\hline CV $(\%)$ & 14.75 & 12.68 & 19.96 & 15.88 & 15.29 \\
\hline
\end{tabular}

Note: Means followed by the same letters are not significantly different according to the LSD test at $5 \%$

The results showed that there was no significant effect of the treatments on the essential macronutrients $(\mathrm{N}, \mathrm{P}, \mathrm{K}, \mathrm{Ca}$ and $\mathrm{Mg}$ ) levels in the soybean plants. It represents that the use of SBE and DBE as filler materials for NPK fertilizer does not affect the concentrations of N, P, K, Ca and $\mathrm{Mg}$ in the plant tissues. Vitosh et al. (1995) reported that the sufficient range of $\mathrm{N}, \mathrm{P}, \mathrm{K}, \mathrm{Ca}$ and $\mathrm{Mg}$ for soybean plants was $4.25-5.50 \%$, $0.30-0.50 \%, 2.10-2.50 \%, 0.36-2 \%$ and $0.26-1 \%$, respectively. Based on these results, soybean plants are deficient in N, P and $\mathrm{K}$ nutrients, while the nutrients $\mathrm{Ca}$ and $\mathrm{Mg}$ are sufficient.

The low level of $\mathrm{N}$ in plants is caused by a low level of $\mathrm{N}$ in the soil (Table 3). In addition, $\mathrm{N}$ is an element that is classified as very mobile so that its presence in the soil quickly changes or even disappears through denitrification, volatilization, transportation of crops, washing and soil surface erosion. The results of soil analysis portrayed that the potential $\mathrm{P}_{2} \mathrm{O}_{5}$ and available $\mathrm{P}$ of the soil were classified as moderate to extremely high (Table 3). However, those contained in the plant tissues were low. It is probably because the plants cannot absorb all of the P elements in the soil (Solihin et al., 2018). The $\mathrm{P}$ elements that are not absorbed by plants will not be washed away but will be stable $\mathrm{P}$ that is not available for plants (Pitaloka, 2004). $\mathrm{K}$ is as easy to be washed as $\mathrm{N}$ and as mobile as $\mathrm{P}$ in soil solution. The deficiency of these elements in plant tissue is caused by competition for nutrient absorption with other ions. The uptake of $\mathrm{K}$ by plants depends not only on the concentration of $\mathrm{K}$ in the soil but also on the composition of cations, such as excessive $\mathrm{NH}_{4}{ }^{+}$, $\mathrm{Ca}^{2+}$, or $\mathrm{Mg}^{2+}$, which disrupt the $\mathrm{K}$ uptake by plants. According to Fageria (2001), $\mathrm{K}^{+}$ions have an antagonistic effect on $\mathrm{Ca}^{2+}$ or $\mathrm{Mg}^{2+}$ at high levels, depending on the plant species and environmental conditions.

Nutrient content by itself is rather difficult to confirm, so data related to uptake of these elements are needed by considering plant biomass. It is important to know the quantity of nutrients used by the plant. The uptake of essential macronutrients of $\mathrm{N}, \mathrm{P}, \mathrm{K}, \mathrm{Ca}$ and $\mathrm{Mg}$ in soybean plants is presented in Table 8 .

Table 8 . Nutrient uptake of $\mathrm{N}, \mathrm{P}, \mathrm{K}, \mathrm{Ca}$ and $\mathrm{Mg}$ by soybean plants as affected by various fertilization treatments at 70 DAP

\begin{tabular}{cccccc}
\hline \multirow{2}{*}{ Treatment } & $\mathrm{N}$ & $\mathrm{P}$ & $\mathrm{K}$ & $\mathrm{Ca}$ & $\mathrm{Mg}$ \\
\cline { 2 - 6 } & & & $\left(\mathrm{g} \mathrm{plant} \mathrm{I}^{-1}\right)$ & & \\
\hline NPK + 10\% bentonite clay & $2.024 \mathrm{a}$ & $0.063 \mathrm{a}$ & $0.417 \mathrm{a}$ & $1.311 \mathrm{a}$ & $0.183 \mathrm{a}$ \\
NPK + 5\% bentonite clay + 5\% SBE & $2.702 \mathrm{a}$ & $0.064 \mathrm{a}$ & $0.394 \mathrm{a}$ & $1.249 \mathrm{a}$ & $0.197 \mathrm{a}$ \\
NPK + 5\% bentonite clay + 5\% DBE & $2.717 \mathrm{a}$ & $0.075 \mathrm{a}$ & $0.447 \mathrm{a}$ & $1.479 \mathrm{a}$ & $0.235 \mathrm{a}$ \\
\hline CV $(\%)$ & 20.30 & 17.73 & 19.83 & 15.46 & 17.50 \\
\hline
\end{tabular}

Note: Means followed by the same letters are not significantly different according to the LSD test at 5\%

The results presented in Table 8 demonstrate that the nutrient uptake of $\mathrm{N}, \mathrm{P}, \mathrm{K}, \mathrm{Ca}$ and $\mathrm{Mg}$ is not affected by the three treatments at 70 DAP. This result confirms that the use of SBE and DBE as filler in NPK fertilizer does not affect the uptake of essential macronutrients in the soybean plants.

In addition to the things previously described, the levels of N, P, K, Ca and $\mathrm{Mg}$ can be thought to be related to the levels of heavy metals that are 
also present in the plant tissues. The relationship between heavy metals and nutrient content in plant tissue can be explained by the correlation presented in Table 9.

Table 9. Correlation between nutrients and heavy metals in the soybean plant tissues as affected by various fertilizer treatments

\begin{tabular}{cccccccccc}
\hline & $\mathrm{N}$ & $\mathrm{P}$ & $\mathrm{K}$ & $\mathrm{Ca}$ & $\mathrm{Mg}$ & $\mathrm{Ag}$ & $\mathrm{Cu}$ & $\mathrm{Ni}$ & $\mathrm{Zn}$ \\
\hline $\mathrm{N}$ & 1.00 & & & & & & & & \\
$\mathrm{P}$ & -1.00 & 1.00 & & & & & & & \\
$\mathrm{~K}$ & -0.68 & 0.68 & 1.00 & & & & & & \\
$\mathrm{Ca}$ & -0.46 & 0.45 & $0.96^{* *}$ & 1.00 & & & & & \\
$\mathrm{Mg}$ & 0.38 & -0.39 & 0.42 & 0.65 & 1.00 & & & & \\
$\mathrm{Ag}$ & 0.12 & -0.11 & -0.80 & $-0.94^{*}$ & -0.87 & 1.00 & & & \\
$\mathrm{Cu}$ & -0.56 & 0.55 & $0.99^{* *}$ & $0.99^{* * *}$ & 0.55 & $-0.89^{*}$ & 1.00 & & \\
$\mathrm{Ni}$ & $-0.99^{* *}$ & $-0.98^{* *}$ & -0.80 & -0.60 & 0.22 & 0.28 & -0.69 & 1.00 & \\
$\mathrm{Zn}$ & 0.71 & -0.71 & 0.03 & 0.30 & $0.92^{*}$ & -0.62 & 0.19 & 0.58 & 1.00 \\
\hline
\end{tabular}

Note: $* * *$ significantly different at $0.1 \%$;** significantly different at $1 \%$; and $*$ significantly different at $5 \%$

As demonstrated in Table 9, sufficient $\mathrm{Ca}$ and $\mathrm{Mg}$ can be related to $\mathrm{Cu}$ levels in plant tissues. Increased $\mathrm{Cu}$ levels will also be followed by an increase in $\mathrm{Ca}$ and $\mathrm{Mg}$ levels in plant tissues (Table 7). This result is in line with the results of research by Lidon and Henriques (1993), reporting that $\mathrm{Cu}$ treatment can increase the levels of $\mathrm{Ca}$ and $\mathrm{Mg}$ in the root tissue of rice plants. The low level of $\mathrm{N}$ in plant tissues can also be caused by $\mathrm{Cu}$ levels in plant tissues. Increased levels of $\mathrm{Cu}$ will be followed by a decrease in $\mathrm{N}$ levels in plant tissue and vice versa. Weber et al. (1991) in their study reported a significant reduction in nitrogen levels in the form of $\mathrm{NO}_{3}{ }^{-}$ $/ \mathrm{NO}_{2}{ }^{-}, \mathrm{NH}_{4}{ }^{+}, \mathrm{N}$-amino acids and $\mathrm{N}$-protein in Silene vulgaris (Moench.) Garcke treated with $\mathrm{Cu}$. Siedlecka (1995) added that $\mathrm{Cu}$ could reduce the $\mathrm{N}$ content in the leaves of wheat. This process depends on the form of $\mathrm{N}$ (the greater antagonism is in the form of $\mathrm{NH}_{4}^{+}$), which is determined by several aspects such as competition between $\mathrm{Cu}^{2+}$ and $\mathrm{NH}_{4}{ }^{+}$in membrane carriers and changes in the activity of some enzymes such as nitrite reductase and glutamine synthase resulting in a certain amino acid deficiency.

$\mathrm{Ni}$ is known to reduce the levels of $\mathrm{P}$ and $\mathrm{K}$ in the plant tissues (Table 9). According to Brune and Dietz (1995), Ni levels that exceed the critical limit can significantly reduce the levels of $\mathrm{P}$ and $\mathrm{K}$ in leaf and root tissues in barley plants. Lavres et al. (2016) reported that high Ni levels could reduce $\mathrm{K}$ levels in soybean plant tissue. Besides affected by $\mathrm{Ni}$, the level of $\mathrm{P}$ is also influenced by $\mathrm{Zn}$ (Table 9), which is in line with the statement of Soltangheisi et al. (2014), reporting that $\mathrm{Zn}$ can contribute to the formation of chemical bonds with phosphate anions $\left(\mathrm{H}_{2} \mathrm{PO}_{4}{ }^{-}\right.$ or $\left.\mathrm{HPO}_{4}{ }^{2-}\right)$ in the soil and make $\mathrm{P}$ unavailable. The $\mathrm{P}-\mathrm{Zn}$ bond is relatively strong and hardly separated, thereby making $\mathrm{P}$ in the soil not available to plants.

\section{CONCLUSIONS}

The results showed that the SBE and DBE materials could partially replace the filler components in bentonite clay filler-based NPK fertilizers, which were shown to have the same effect on soil chemical properties and levels of heavy metals after treatment, levels and uptake of $\mathrm{N}, \mathrm{P}, \mathrm{K}, \mathrm{Ca}$ and $\mathrm{Mg}$ in plants tissues and growth characteristic in the form of total dry weight. Further research is required regarding the probability of increasing the percentage of SBE and DBE used to substitute bentonite clay minerals in NPK fertilizer, in a proportion $>5 \%$ of the NPK weight, so that SBE waste can be maximally utilized without causing a decrease in crop yields and environmental pollution.

\section{ACKNOWLEDGEMENT}

The authors would like to thank Wilmar Group Indonesia for funding this research.

\section{REFERENCES}

Alloway, B. J. (1995). Heavy metals in soils (2nd ed.). London: Blackie Academic \& Professional.

Anugrah, C., Indradewa, D., \& Putra, E. T. S. (2020). Biochemical response of hybrid maize (Zea mays L.) to NPK fertilization based on 
spent bleaching earth in field scale. E3S Web of Conferences, 142, 1-9. https://doi.org/ 10.1051/e3sconf/202014201004

Apriliani, I. N., Heddy, S., \& Suminarti, N. E. (2016). Pengaruh kalium pada pertumbuhan dan hasil dua varietas tanaman ubi jalar (Ipomea batatas (L.) Lamb). Jurnal Produksi Tanaman, 4(4), 264-270. Retrieved from http://protan.studentjournal.ub.ac.id/index.ph p/protan/article/view/290

Ashfaque, F., Inam, A., Sahay, S., \& Iqbal, S. (2016). Influence of heavy metal toxicity on plant growth, metabolism and its alleviation by phytoremediation - A promising technology. Journal of Agriculture and Ecology Research International, 6(2), 1-19. https://doi.org/ 10.9734/jaeri/2016/23543

Barrena, R., Casals, E., Colón, J., Font, X., Sánchez, A., \& Puntes, V. (2009). Evaluation of the ecotoxicity of model nanoparticles. Chemosphere, 75(7), 850-857. https://doi.org/ 10.1016/j.chemosphere.2009.01.078

Benson, N. (2014). Trace metals levels in inorganic fertilizers commercially available in Nigeria. Journal of Scientific Research and Reports, 3(4), 610-620. https://doi.org/ 10.9734/jsrr/2014/7465

Brune, A., \& Dietz, K. J. (1995). A Comparative analysis of element composition of roots and leaves of barley seedlings grown in the presence of toxic cadmium, molybdenum, nickel, and zinc concentrations. Journal of Plant Nutrition, 18(4), 853-868. https://doi. org/10.1080/01904169509364943

Chanrai, N. G., \& Burde, S. G. (2004). Recovery of oil from spent bleached earth (Patent No. 10/188,810). Retrieved from https://patents. google.com/patent/US6780321B2/en

Delgado, A., \& Gómez, J. A. (2016). The Soil. Physical, Chemical and Biological Properties. In Principles of Agronomy for Sustainable Agriculture. Springer International Publishing AG. https://doi.org/10.1007/978-3-319-46116 $-8$

Emamverdian, A., Ding, Y., Mokhberdoran, F., \& Xie, Y. (2015). Heavy metal stress and some mechanisms of plant defense response. Scientific World Journal, 2015, 7-9. https:// doi.org/10.1155/2015/756120
Erfandy, D., \& Juarsah, I. (2014). Teknologi pengendalian pencemaran logam berat pada lahan pertanian. In Konservasi tanah menghadapi perubahan iklim. Balai Penelitian Tanah, pp. 159-186. Retieved from http:// balittanah.litbang.pertanian.go.id/ind/dokume ntasi/buku/bungarampai07.pdf

Erizilina, E., Pamoengkas, P., \& Darwo, D. (2018). Hubungan sifat fisik dan kimia tanah dengan pertumbuhan meranti merah di KHDTK Haurbentes. Jurnal Pengelolaan Sumberdaya Alam dan Lingkungan (Journal of Natural Resources and Environmental Management), 8(2), 216-222. https://doi.org/ 10.29244/jpsl.8.2.216-222

Eviati, \& Sulaeman. (2009). Petunjuk teknis analisis kimia tanah, tanaman, air, dan pupuk (2nd ed). Bogor: Balai Penelitian Tanah. Retrieved from http://balittanah.litbang.perta nian.go.id/ind/dokumentasi/juknis/juknis_kim ia2.pdf.

Fageria, N. K., Baligar, V. C., \& Jones, C. A. (1997). Growth and mineral nutrition of field crop (1st ed). Marcel Dekker. Inc.

Fageria, V. D. (2001). Nutrient interactions in crop plants. Journal of Plant Nutrition, 24(8), 1269-1290. http://dx.doi.org/10.1081/PLN-10 0106981

Fitriani, R. N., Budiyanto, S., \& Sukarjo, S. (2019). Respon tanaman kedelai (Glycine max L. Merill) pada berbagai konsentrasi cemaran ion logam $\mathrm{Ni}^{2+}$ dengan pemberian biokompos. Journal of Agro Complex, 3(3), 184-193. https://doi.org/10.14710/joac.3.3.184-193

Ginting, E. N., Sutandi, A., Nugroho, B., \& Indriyati, L. T. (2013). Rasio dan kejenuhan hara $\mathrm{K}, \mathrm{Ca}, \mathrm{Mg}$ di dalam tanah untuk tanaman kelapa sawit (Elaeis guineensis Jacq). Jurnal Ilmu Tanah Dan Lingkungan, 15(2), 60-65. https://doi.org/10.29244/jitl.15.2.60-65

Handayanto, E., Nuraini, Y., Muddarisna, N., Netty, S., \& Fiqri, A. (2017). Fitoremediasi dan Phytomining Logam Berat Pencemar Tanah. Malang: UB Press.

Harmoni, K. (2014). Analisis persebaran iklim klasifikasi Oldeman di Provinsi Daerah Istimewa Yogyakarta [Undergraduate thesis]. Surakarta: Fakultas Geografi, Universitas Muhammadiyah Surakarta. 
Retrieved from http://eprints.ums.ac.id/32184/ 15/NASKAH\%20PUBLIKASI.pdf

Hermawan, A. R. (2017). Pengaruh coating kitosan terhadap daya tahan dan penyerapan air pada formulasi pupuk granul [Undergraduate thesis]. Bogor: Institut Pertanian Bogor. Retrieved from https:// repository.ipb.ac.id/handle/123456789/85543

Krisyanti, S., \& Sukandar. (2011). Recovery minyak dari limbah bahan berbahaya dan beracun (B3) spent bleaching earth dengan metode ekstraksi pelarut. Jurnal Teknik Lingkungan, 17(1), 35-46. Retrieved from https://ftsl.itb.ac.id/wp-content/uploads/sites/ 8/2017/03/4.-Sri-Krisyanti-Sukandar.pdf

Lavres, J., Franco, G. C., \& Câmara, G. M. S. (2016). Soybean seed treatment with nickel improves biological nitrogen fixation and urease activity. Frontiers in Environmental Science, 4, 37. https://doi.org/10.3389/fenvs. 2016.00037

Li, C., Dang, F., Li, M., Zhu, M., Zhong, H., Hintelmann, H., \& Zhou, D. (2017). Effects of exposure pathways on the accumulation and phytotoxicity of silver nanoparticles in soybean and rice. Nanotoxicology, 11(5), 699709. https://doi.org/10.1080/17435390.2017.1 344740

Lidon, F. C., \& Henriques, F. S. (1993). Effects of copper toxicity on growth and the uptake and translocation of metals in rice plants. Journal of Plant Nutrition, 16(8), 1449-1464. https:// doi.org/10.1080/01904169309364626

Loh, S. K., Cheong, K. Y., Choo, Y. M., \& Salimon, J. (2015). Formulation and optimisation of spent bleaching earth-based bio organic fertiliser. Journal of Oil Palm Research, 27(1), 57-66. Retrieved from http://jopr.mpob.gov.my/wp-content/uploads/ 2015/03/Pages-from-JOPR271_web-61.pdf

Mba, O. I., Dumont, M. J., \& Ngadi, M. (2015). Palm oil: Processing, characterization and utilization in the food industry - A review. Food Bioscience, 10, 26-41. https://doi.org/ 10.1016/j.fbio.2015.01.003

Mousavi, S. R., Galavi, M., \& Rezaei, M. (2012). The interaction of zinc with other elements in plants: A review. International Journal of Agriculture and Crop Sciences, 4(24), 1881-
1884. Retrieved from https://www.cabdirect. org/cabdirect/abstract/20133031574

Mustikawati, D., Suntoro, \& Pardono. (2019). The effect of cow manure application and watering interval on patchouli growth in regosol soil. IOP Conference Series: Earth and Environmental Science, 250(1), 1-5. https://doi.org/10.1088/1755-1315/250/1/012 086

Nair, P. M. G., \& Chung, I. M. (2014). A mechanistic study on the toxic effect of copper oxide nanoparticles in soybean (Glycine max L.) root development and lignification of root cells. Biological Trace Element Research, 162(1-3), 342-352. https://doi.org/10.1007/s1 2011-014-0106-5

Nariratih, I., Damanik, M. M. B., \& Sitanggang, G. (2013). Ketersediaan nitrogen pada tiga jenis tanah akibat pemberian tiga bahan organik dan serapannya pada tanaman jagung. Jurnal Agroeko-teknologi Universitas Sumatera Utara, 1(3), 479-488. https://doi.org /10.32734/jaet.v1i3.2645

Nursyamsi, D., \& Setyorini, D. (2009). Ketersediaan P tanah-tanah netral dan alkalin. Jurnal Tanah dan Iklim, 30, 25-36. Retrieved from http://balittanah.litbang.deptan.go.id/eng /dokumentasi/prosiding2008pdf/dedy_nur_alk alin.pdf

Pasaribu, K. F., \& Sukandar, S. (2017). Analisis manfaat biaya pengelolaan limbah spent bleaching earth melalui pemanfaatan dan penimbunan dengan memperhitungkan nilai gas rumah kaca. Jurnal Tehnik Lingkungan, 23(2), 33-42. https://doi.org/10.5614/j.tl.2017 .23 .2 .4

Pitaloka, N. D. A. (2004). Uji efektivitas ketersediaan unsur fosfat pada tanah typic tropoquent dataran alluvial berdasarkan dosis dan waktu inkubasi. Jurnal Agrifar, 2(3), 7075. Retrieved from https://scholar.google.co. $\mathrm{id} /$ scholar?cluster $=17628602925160316540 \&$ $\mathrm{hl}=\mathrm{id} \&$ as_sdt $=2005 \&$ sciodt $=0,5 \&$ authuser $=3$ $\&$ scioq $=+$ Uji+efektivitas+ketersediaan+unsur + fosfat+pada+tanah+typic+tropoquent+datara $\mathrm{n}+$ alluvial+berdasarkan+dosis+dan+waktu+in kubasi.+

Pratap, A., Gupta, S. K., Kumar, J., \& Solanki, R. K. (2012). Soybean. In Technological 
innovations in major world oil crops, Volume 1: Breeding. Springer Science+Business Media. https://doi.org/10.1007/978-1-4614-03 56-2

Purba, R. S., Irwan, S. N. R., \& Putra, E. T. S. (2020). The effect of spent bleaching earth filler-based npk fertilization on proline, growth and yield of maize. Caraka Tani: Journal of Sustainable Agriculture, 35(1), 4453. https://doi.org/10.20961/carakatani.v35i1. 34166

Rai, P. K., Lee, S. S., Zhang, M., Tsang, Y. F., \& Kim, K.-H. (2019). Heavy metals in food crops: Health risks, fate, mechanisms, and management. Environment International, 125, 365-385. https://doi.org/10.1016/j.envint.201 9.01 .067

Sevindrajuta. (1996). Peranan cacing tanah (Pontoscolex corethrurus) dan macam bahan organik dalam perbaikan beberapa sifat fisika Ultisol Rimbo Data dan hasil kedelai [Master thesis]. Padang: Universitas Andalas. Universitas Andalas.

Sharma, P. N., Kumar, N., \& Bisht, S. S. (1994). Effect of zinc deficiency on chlorophyll contents, photosyntehsis, and water relations of cauliflower plants. Photosyntehtica, 30, 353-359. Retrieved from https://agris.fao.org/ agris-search/search.do?recordID=CZ9500369

Shofi, M. (2017). Daya hambat perak nitrat $\left(\mathrm{AgNO}_{3}\right)$ pada perkecambahan biji kacang hijau (Vigna radiata). Al-Kauniyah: Jurnal Biologi, 10(2), 98-104. https://doi.org/ 10.15408/kauniyah.v10i2.4869

Siedlecka, A. (1995). Some aspects op interactions between heavy metals and plant mineral nutrients. Acta Societatis Botanicorum Poloniae, 64(3), 265-272. https://doi.org/ 10.5586/asbp. 1995.035

Sinaga, R. A., Kurniasih, B., \& Putra, E. T. S. (2021). Growth and yield of soybean as a response of the fertilization of NPK compound produced with spent and deoiled bleaching earth filler. Caraka Tani: Journal of Sustainable Agriculture, 36(1), 11-19. https:// doi.org/10.20961/carakatani.v36i1.35682

Smith, J. C. Jr. (1982). Interrelationship of zinc and vitamin A metabolism in animal and human nutrition: A review. In Clinical,
Biochemical and Nutritional Aspects of Trace Elements. New York: A. S. Prasad, ed., Alan R. Liss, Inc.. Retrieved from https://agris.fao. org/agris-search/search.do?recordID=US8608 667

Soeparjono, S. (2016). The effect of media composition and organic fertilizer concentration on the growth and yield of red ginger rhizome (Zingiber officinale Rosc.). Agriculture and Agricultural Science Procedia, 9, 450-455. https://doi.org/10.1016/ j.aaspro.2016.02.162

Solihin, E., Sudirja, R., Damayani, M., \& Kamaludin, N. N. (2018). Hubungan serapan $\mathrm{N}$, P, dan $\mathrm{K}$ tanaman cabai terhadap residunya di dalam tanah yang diberi pupuk cair organik dengan NPK. Agrikultura, 29(2), 105. https:// doi.org/10.24198/agrikultura.v29i2.20807

Soltangheisi, A., Rahman, Z. A., Ishak, C. F., Musa, H. M., \& Zakikhani, H. (2014). Interaction effects of phosphorus and zinc on their uptake and 32P absorption and translocation in sweet corn (Zea mays var. saccharata) grown in a tropical soil. Asian Journal of Plant Sciences, 13(3), 129-135. https://doi.org/10.3923/ajps.2014.129.135

Sonbai, J. H. H., Prajitno, D., \& Syukur, A. (2013). Pertumbuhan dan hasil jagung pada berbagai pemberian pupuk nitrogen di lahan kering regosol. Ilmu Pertanian, 16(1), 77-89. Retrieved from https://jurnal.ugm.ac.id/jip/ article/view/2527

Suhariyono, G., \& Menry, Y. (2005). Analisis karakteristik unsur-unsur dalam tanah di berbagai lokasi dengan menggunakan xrf. Prosiding PPI-PDIPTN, 197-206. https://doi. org/10.1016/j.str.2014.12.012

Taufiq, A. (2014). Identifikasi masalah keharaan tanaman kedelai. Malang: Balai Penelitian Tanaman Aneka Kacang dan Umbi.

Taufiq, A., \& Sundari, T. (2012). Respons tanaman kedelai terhadap lingkungan tumbuh. Buletin Palawija, 23, 13-26. Retrieved from http://ejurnal.litbang.pertanian.go.id/index.ph p/bulpa/article/view/1297

Tjahjadi, N. (1989). Hama dan penyakit tanaman. Yogyakarta: Penerbit Kanisius.

Vispute, P., \& Dabhade, S. (2018). Refining of 
palm oil: A review on palm oil refining process, 3- MCPD esters in refined palm oil, and possible reduction tactics for 3-MCPD esters. International Journal of Agricultural Engineering, 11, 81-85. https://doi.org/ 10.15740/has/ijae/11.sp.issue/81-85

Vitosh, M. L., Johnson, J. W., \& Mengel, D. B. (1995). Tri-state fertilizer recommendations for corn, soybeans, wheat and alfalfa. Extension Bulletin E-2567, 1-21. Retrieved from https://agcrops.osu.edu/FertilityResourc es/tri-state_info

Wambu, E. W., Muthakia, G. K., Shiundu, P. M., \& Thiongo, K. J. (2009). Kinetics of copper desorption from regenerated spent bleaching earth. American-Eurasian Journal of Scientific
Research, 4(4), 317-323. Retrieved from http://erepository.uonbi.ac.ke/handle/11295/3 3991

Weber, M. B., Schat, H., \& Ten Bookum-Van der Maarel, W. M. (1991). The effect of copper toxicity on the contents of nitrogen compounds in Silene vulgaris (Moench) Garcke. Plant Soil, 133, 101-109. https://doi.org/10.1007/ BF00011904

Wisnubroto, M. P., Putra, E. T. S., \& Kurniasih, B. (2020). Tanggapan Biokemis, Fisiologis, dan Agronomis Kedelai (Glycine max L. Merrill) terhadap Pemupukan NPK Berperekat Spent dan Deoiled Bleaching Earth (Unpublished master's thesis). Yogyakarta: Universitas Gadjah Mada. 